Volume 2 Nomor 2, November 2021: h. 126 - 139 P-ISSN: 2722-4465, E-ISSN: 2746-8151

Lisensi Creative Commons Atribusi-NonCommercial 4.0 Internasional

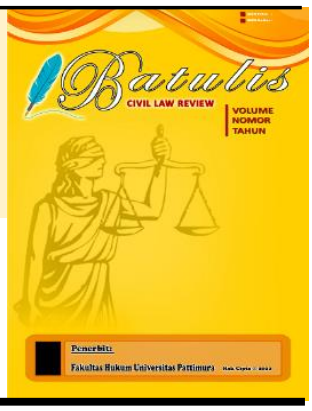

\title{
Transparansi Pengelolaan Badan Usaha Milik Desa Dalam Rangka Optimalisasi Kontribusi Pada Perekonomian Daerah
}

\section{Subhan Ashary Rezky Sanaky}

Pascasarjana Ilmu Hukum Fakultas Hukum Universitas Indonesia, Depok, Indonesia E-mail: sanakytath@gmail.com

\begin{tabular}{|c|c|}
\hline Dikirim: 03/02/2021 & Dipublikasi: 27/11/2021 \\
\hline Info Artikel & Abstract \\
\hline \multirow[t]{2}{*}{$\begin{array}{l}\text { Keywords: } \\
\text { Transparency BUMD; } \\
\text { Management; Optimization; } \\
\text { Regional Economy. }\end{array}$} & $\begin{array}{l}\text { In an optimal and good regional economy, management of BUMD is } \\
\text { very important. One of the good management of BUMD is through } \\
\text { the principle of transparency. This principle is very important. } \\
\text { Management by using the Transparency Principle in the management } \\
\text { of this BUMD must be carried out, so that the BUMD can achieve the } \\
\text { objectives of the establishment of the BUMD. That is supporting the } \\
\text { economy of a region and also contributing to the economy of the region. } \\
\text { The method for this research is descriptive analytical with normative } \\
\text { juridical research using primary, secondary and tertiary data through } \\
\text { literature and document studies. The results showed that the } \\
\text { importance of managing BUMD in transparency through the } \\
\text { principle of transparency is also the best way that can be done } \\
\text { by BUMD to be able to fight crime that occurs within BUMD } \\
\text { itself, which is often still done by parties certain parties to } \\
\text { benefit from the management of BUMD that does not use the } \\
\text { principle of transparency. Transparency is also an important } \\
\text { point in the management of BUMD to be able to realize the } \\
\text { tangible manifestation of improved management of } \\
\text { management and implementation of BUMD that is good and } \\
\text { can also help in reducing opportunities for occurrence } \\
\text { corruption, collusion and Nepotism that continue to occur in the } \\
\text { management of BUMD. }\end{array}$ \\
\hline & Abstrak \\
\hline $\begin{array}{l}\text { Kata Kunci: } \\
\text { Transparansi BUMD; } \\
\text { Pengelolaan; Optimalisasi; } \\
\text { Perekonomian Daerah. }\end{array}$ & $\begin{array}{l}\text { Didalam suatu Perekonomian daerah yang optimal dan baik, } \\
\text { pengelolaan BUMD sangat penting.salah satu pengelolaan } \\
\text { BUMD yang baik adalah melalui prinsip transparansi. Prinsip } \\
\text { ini sangatlah penting.Pengelolaan dengan menggunakan } \\
\text { Prinsip Transparansi didalam pengelolaan BUMD ini wajib } \\
\text { dilakukan, sehingga BUMD bisa mencapai tujuan dari } \\
\text { dibentuknya BUMD tersebut. Yaitu mendukung perekonomian } \\
\text { suatu daerah dan juga memberikan kontribusi pada } \\
\text { perekonomian daerahnya. Metode untuk penelitian ini bersifat } \\
\text { deskriptif analitis dengan jenis penelitian juridis normatif } \\
\text { dengan menggunakan data primer, sekunder dan tersier } \\
\text { melalui studi kepustakaan dan dokumen. Hasil penelitian } \\
\text { menunjukan bahwa pentingnya pengelolaan BUMD secara } \\
\text { transparansi melalui prinsip transparansi ini juga merupakan }\end{array}$ \\
\hline
\end{tabular}


DOI:

10.47268/ballrev.v2i2.688 cara terbaik yang bisa dilakukan oleh BUMD untuk bisa melawan kejahatan yang terjadi didalam BUMD itu sendiri, yang sering kali masih dilakukan oleh pihak-pihak tertentu untuk mendapatkan keuntungan-keuntungan dari pengelolaan BUMD yang tidak menggunakan prinsip tranparansi .Transparansi juga adalah poin penting didalam pengelolaan BUMD untuk bisa mewujudkan yang wujud nyata dari peningkatan manajemen pengelolaan dan penyelenggaraan BUMD yang baik dan juga bisa membantu didalam mengurangi kesempatan-kesempatan untuk terjadinya korupsi, kolusi dan Nepotisme yang terus terjadi didalam pengelolaan BUMD.

\section{Pendahuluan}

Badan Usaha Milik Daerah (BUMD) merupakan usaha yang dimiliki oleh Pemerintah Daerah, yang tujuannya adalah sebagai salah satu sumber penerimaan daerah (PAD). Tapi pada kenyataannya bahwa BUMD yang ada selama ini belum mampu memberikan kontribusi yang signifikan terhadap pendapatan asli daerah (PAD), justru lebih banyak suntikan dana dari pemerintah daerah daripada keuntungan yang di dapat. Kondisi tersebut menjadi beban bagi APBD. Sehingga apa yang menjadi tujuan berdirinya BUMD adalah sebagai salah satu sumber pendapatan pemerintah daerah tidak tercapai (Sarana, 2010: iii).

Didalam Pasal 1 Ayat 40 Undang-Undang Nomor 23 Tahun 2014 Tentang Pemerintahan Daerah, yang mengatur tentang BUMD dijelaskan bahwa Badan Usaha Milik Daerah yang selanjutnya disingkat BUMD adalah badan usaha yang seluruh atau sebagian besar modalnya dimiliki oleh Daerah, dan juga didalam Pasal 1 ayat 1 Peraturan Pemerintah Nomor 54 Tahun 2017 Tentang Badan Usaha Milik Daerah mengenai BUMD dijelaskan bahwa Badan Usaha Milik Daerah yang selanjutnya disingkat BUMD adalah badan usaha yang seluruh atau sebagian besar modalnya dimiliki oleh Daerah.

Sedangkan Pasal 7 Peraturan Pemerintah Nomor 54 Tahun 2017 Tentang Badan Usaha Milik Daerah, dijelaskan bahwa Pendirian BUMD bertujuan untuk memberikan manfaat bagi perkembangan perekonomian Daerah; menyelenggarakan kemanfaatan umum berupa penyediaan barang dan/atau jasa yang bermutu bagi pemenuhan hajat hidup masyarakat sesuai kondisi, karakteristik dan potensi Daerah yang bersangkutan berdasarkan tata kelola perusahaan yang baik; dan memperoleh laba dan/atau keuntungan.

Apabila dilihat dari fungsi dan peranan yang dimiliki oleh BUMD itu sendiri. BUMD memiliki berbagai fungsi dan peranan yang dibebankan kepadanya, utamanya adalah: 1 . Melaksanakan kebijakan pemerintah di bidang ekonomi dan pembangunan daerah; 2 . Pemupukan dana bagi pembiayaan pembangunan daerah; 3. Mendorong peran serta masyarakat dalam bidang usaha; 4 . Memenuhi kebutuhan barang dan jasa bagi kepentingan publik; dan 5. Menjadi perintis kegiatan dan usaha yang kurang diminati swasta (Kamaluddin, 2011: 2). 
Jika diilhat dari pembentukan dan pengelolaan BUMD Menurut Harefa (Harefa, 2016: 15) bahwa pembentukan dan pengelolaan BUMD hendaknya dilihat dari kepentingan dalam tujuannya yang benar-benarnmemiliki kepentingan bagi masyarakat umum agar penyertaan modal yang diberikan pemda dapat optimal. Lebih lanjut dijelaskan oleh Alwi (Alwi, 2002: 11) mengajak untuk melihat kembali definisi tentang BUMD, sebagai perusahaan profesional atau hanya sekedar perusahaan daerah. Jika BUMD diposisikan sebagai perusahaan profesional maka, BUMD juga harus menjalankan perusahaan dengan profesional dan memiliki tata kelola perusahaan yang jelas serta terarah.

Didalam pengelolaan BUMD yang terarah dan jelas diperlukan suatu transparansi dalam pengelolaannya. Dimana apa bila dijelaskan secara singkat Transparansi adalah keterbukaan dalam melaksanakan proses pengambilan keputusan dan keterbukaan dalam mengemukakan informasi materiil dan relevan mengenai perusahaan.Bushman \& Smith (Bushman \& Smith, 2003: 76) mengartikan transparansi sebagai ketersediaan informasi tanpa batas, informasi yang relevan yang dapat diandalkan tentang kinerja periodik,posisi keuangan, peluang investasi, tata kelola, nilai, dan risiko perusahaan publik.

Menurut Badan Perencanaan Pembangunan Nasional \& Departemen Dalam Negeri dalam Loina Lalolo Krina P Transparansi merupakan prinsip yang menjamin akses atau kebebasan bagi setiap orang untuk memperoleh informasi tentang penyelenggaraan pemerintahan, yakni meliputi informasi tentang kebijakan, proses pembuatan dan pelaksanaannya, serta hasil-hasil yang dicapai. Transparansi yakni adanya kebijakan terbuka bagi pengawasan, sedangkan yang dimaksud dengan informasi adalah informasi mengenai setiap aspek kebijakan pemerintah yang dapat dijangkau oleh publik. Keterbukaan informasi diharapkan akan menghasilkan persaingan politik yang sehat, toleran, dan kebijakan dibuat berdasarkan pada preferensi publik (P, 2003: 20).

Transparansi juga merupakan prinsip yang menjamin akses atau kebebasan bagi setiap orang untuk memperoleh informasi tentang penyelenggaraan pemerintahan, yakni meliputi informasi tentang kebijakan, proses pembuatan dan pelaksanaannya, serta hasil-hasil yang dicapai. Transparansi yakni adanya kebijakan terbuka bagi pengawasan, sedangkan yang dimaksud dengan informasi adalah informasi mengenai setiap aspek kebijakan pemerintah yang dapat dijangkau oleh publik.Keterbukaan informasi diharapkan akan menghasilkan persaingan politik yang sehat, toleran, dan kebijakan dibuat berdasarkan pada preferensi publik. Transparansi berarti suatu keterbukaan secara nyata, menyeluruh, dan memberi ruang kepada seluruh lapisn masyarakat untuk berpartisipasi secara aktif dalam proses pengelolaan sumber daya publik. Apabila dikaitkan dengan anggaran, transparansi dapat didefinisikan sebagai keterbukaan kepada masyarakat yang meliputi fungsi dan struktur pemerintah, tujuan kebijakan fiskal, sektor keuangan publik, dan proyeksi-proyeksinya (Andrianto, 2007: 20).

Namun demikian, dalam era perusahaan modern, transparansi sudah menjadi sebuah kewajiban yang harus dipenuhi oleh perusahaan. Perusahaan dalam era 
modern bukan lagi sebuah perkumpulan tertutup yang penuh dengan kerahasiaan, melainkan sebuah organisasi yang selalu melakukan interaksi dengan banyak pihak. Transparansi merupakan bagian yang tidak terpisahkan dari prinsip good corporate governance.Bahkan dalam banyak sumber, transparansi juga dikaitkan dengan akuntabilitas.Transparansi dan akuntabilitas menjadi kekuatan utama dalam pelaksanaan good corporate governance (Amdanata et al., 2019: 156).

Indonesia, setelah mengalami krisis ekonomi pada tahun 1998, berusaha memperkuat tata kelola perusahaan. Salah satu penyebab ekonomi Indonesia goyah pada masa krisis ekonomi itu adalah karena lemahnya pelaksanaan prinsip GCG. PP No. 54 Tahun 2017 Tentang BUMD merupakan salah satu upaya pemerintah untuk memperkuat implementasi prinsip GCG pada BUMD. Hal ini tentu saja bukan tanpa alasan, sebab sejak dimulainya era otonomi daerah dan pemerintahdaerah di beri kesempatan mendirikan BUMD, sudah 113 BUMD yang akhirnya beroperasi di Indonesia. Namun yang membuat masyarakat marah adalah BUMD selalu mengalami kerugian. Bahkan pada beberapa provinsi terdapat direksiBUMD yang bermasalah dengan hukum (Amdanata et al., 2019), dalam penerapan good corporate governance dibutuhkan unsur yang mendukung. Adapun unsur-unsur tersebut adalah (Azre, 2017: 194):

a. Corporate governance- internal perusahaan Unsur-unsur yang berasal dari perusahaan adalah:

1) Pemegang saham;

2) Direksi;

3) Dewan komisaris;

4) Manajer;

5) Karyawan;

6) Sistem remunerasi berdasarkan kinerja;

7) Komite audit.

Unsur-unsur yang selalu diperlukan di dalam perusahaan, antara lain meliputi:

1) Keterbukaan dan kerahasiaan;

2) Transparansi;

3) Akuntabilitas;

4) Kesetaraan;

5) Aturan dari code of conduct.

b. Corporate governance- eksternal perusahaan

Unsur-unsur yang berasal dari luar perusahaan adalah:

1) Kecukupan undang-undang dari perangkat hukum;

2) Investor;

3) Institusi penyedia informasi;

4) Akuntan publik;

5) Pemberi pinjaman;

6) Institusi yang memihak kepentingan publik bukan golongan;

7) Lembaga yang mengesahkan legalitas. Unsur-unsur yang selalu diperlukan diluar perusahaan antara lain meliputi: 
a) Aturan dari code of conduct;

b) Kesetaraan;

c) Akuntabilitas;

d) Jaminan hukum.

Dari definisi dan juga penjelasan yang sudah dijelaskan, dapat disimpulkan bahwa transparansi adalah keterbukaan pemerintah kepada publik tentang semua informasi yang berkaitan dengan aktivitas penyelenggaraan pemerintahan. Adanya transparansi anggaran membawa dampak positif bagi kepentingan publik. Beberapa manfaat penting adanya transparansi anggaran yaitu dapat mencegah terjadinya korupsi, mudah dalam mengidentifikasi kelemahan dan kekuatan kebijakan, meningkatkan akuntabilitas pemerintah sehingga masyarakat akan lebih mampu mengukur kinerja pemerintah, meningkatkan kepercayaan terhadap komitmen pemerintah untuk memutuskan kebijakan tertentu, menguatkan kohesi sosial, karena kepercayaan publik terhadap pemerintah akan terbentuk, dan menciptakan iklim investigasi yang lebih baik sehingga dapat meningkatkan kepastian usaha (Azre, 2017: 21).

Permasalahan transparansi adalah suatu permasalahan besar yang terjadi di Indonesia.Dimana BUMD yang masih belum transparan didalam pengelolaannya, dimana hal ini menimbulkan rasa ketidakpercayaan masyarakat pada BUMD sehingga apabila masih saja terus terjadi bisa menjadi suatu masalah besar kedepannya.Masalah tranparansi pada sudah seharusnya diselesaikan agar tidak menjadi permasalahan yang semakin besar.

Didalam pengelolaan BUMD sesuai dengan PP No 54 Tahun 2017 soal BUMD, ditekankan tentang transparansi, didalam proses pengelolaan dan tata kelola perusahaan yang baik adalah transparansi, akuntabilitas, pertanggung jawaban. Kemandirian dan kewajaran, dimana penerapan tata kelola perusahaan yang baik sebagaimana dijelaskan sebelumnya bertujuan untuk:

a) Mencapai tujuan BUMD.

b) Mengoptimalkan nilai BUMD agar perusahaan memiliki daya saing yang kuat, baik secara professional, efisien dan efektif serta memberdayakan fungsi dan meningkatkan kemandirian organ BUMD.

c) Mendorong pengelolaan BUMD secara profesional, efisien, dan efektif, serta memberdayakan fungsi dan meningkatkan kemandirian organ BUMD.

d) Mendorong agar organ BUMD dalam membuat keputusan dan menjalankan tindakan dilandasi nilai moral yang tinggi dan kepatuhan terhadap peraturan perundang-undangan, serta kesadaran tanggung jawab sosial BUMD terhadap pemangku kepentingan maupun kelestarian lingkungan di sekitar BUMD;

e) Meningkatkan kontribusi BUMD dalam perekonomian nasional; dan

f) Meningkatkan iklim usaha yang kondusif bagi perkembangan investasi nasional. 
Tata kelola perusahaan yang baik seperti yang sudah dijelaskan ditetapkan oleh direksi. Berdasarkan aturan yang mengatur mengenai pengelolaan BUMD seharusnya sudah cukup jelas pengaturan mengenai transparansi didalam pengelolaan BUMD. Hal ini kemudian menjadi sebuah pertanyaan besar kenapa masih ada masalah dan kasus tidak ada nya tranparansi didalam pengelolaan BUMD di beberapa daerah di Indonesia. Yang didalam fokus penulisan ini adalah di daerah Banten.

\section{Hasil dan Pembahasan}

Menurut Mardiasmo, transparansi berarti keterbukaan (opennsess) pemerintah dalam memberikan informasi yang terkait dengan aktivitas pengelolaan seumberdaya publik kepada pihak-pihak yang membutuhkan informasi. Pemerintah berkewajiban memberikan informasi keuangan dan informasi lainya yang akan digunakan untuk pengambilan keputusan oleh pihak - pihak yang berkepentingan (Mardiasmo, 2004: 30). Transparansi pada akhirnya akan menciptakan horizontal accountability antara pemerintah daerah dengan masyarakat sehingga tercipta pemerintahan daerah yang bersih, efektif, efisien, akuntabel dan responsif terhadap aspirasi dan kepentingan masyarakat. Transparansi adalah prinsip yang menjamain akses atau kebebasan bagi setiap orang untuk memperoleh informasi tentang penyelenggaraan pemerintahan, yakni informasi tentang kebijakan proses pembuatan dan pelaksanaanya serta hasil-hasil yang dicapai (Bappenas \& Depdagri, 2002: 18).

Selain itu juga bisa didefinisikan bahwa, Transparansi adalah adanya kebijakan terbuka bagi pengawasan. Sedangkan yang dimaksud dengan informasi adalah informasi mengenai setiap aspek kebijakan pemerintah yang dapat dijangkau publik. Keterbukaan informasi diharapkan akan menghasilkan persaingan politik yang sehat, toleran, dan kebijakan dibuat berdasarkan preferensi publik (Rahman, 2000: 151).

Makna dari transparansi dalam penyelenggaraan pemerintahan daerah dapat dilihat dalam dua hal yaitu; (1) salah satu wujud pertanggung jawaban pemerintah kepada rakyat, dan (2) upaya peningkatan manajemen pengelolaan dan penyelenggaraan pemerintahan yang baik dan mengurangi kesempatan praktek kolusi, korupsi dan nepotisme (KKN) (BKSI, 2001: 2).

Didalam hukum yang mengatur mengenai BUMD yaitu Peraturan Pemerintah Nomor 54 Tahun 2017 soal BUMD,juga menjelaskan dan mengatur dengan jelas mengenai pentingnya tranparansi didaam pengelolaan BUMD, dimana bertujuan untuk BUMD Dapat Mencapai Tujuan Mereka, Mengoptimalkan nilai BUMD agar perusahaan memiliki daya saing yang kuat, baik secara professional, efisien dan efektif dan juga meningkatkan perekonomian daerah.

Ketika membahas mengenai mengenai kasus tidak tranparansinya pengelolaan BUMD di Indonesia dapat dikatakan merupakan suatu kejadian yang masih terus terjadi dikarenakan masih kurangnya kesadaran akan pentingnya transparansi didalam pengelolaan BUMD yang baik agar bisa menjadi BUMD yang memberikan 
kontribusi baik didalam perekonomian Daerah, selain itu masih kurang adanya penanganan dan pengawasan yang baik untuk penyelesaian masalah tidak transparansinya pengelolaan BUMD tersebut. Pada daerah Banten, salah satu daerah di Indonesia yang masih terjadi kasus seperti korupsi di BUMD Banten disebabkan karena tidak adanya transparansi dalam pelaporan keuangan BUMD sehingga menyebabkan munculnya kasus didalam BUMD yang kemudian merugikan keuangan daerah dan keuangan Negara.

Apabila kita melihat pada pengertiannya, Menurut Kamus Besar Bahasa Indonesia, Korupsi berasal dari kata korup yang berarti rusak,busuk,dapat disogok, sedangkan kata korupsi berarti penyelewengan atau penyalahgunaan uang negara (perusahaan dsb) untuk keuntungan pribadi atau orang lain (Pusat Bahasa Departemen Pendidikan Nasional, 2008: 596-597). Sedangkan didalam Black Law Dictionary, Sixth Edition, mengartikan korupsi sebagai berikut. "An Act done with an intent to give some advantage incosistent with official duty and the right of other" (Black, 1990: 345). Dapat diartikan secara bebas: Suatu perbuatan yang dilakukan dengan maksud untuk memberikan suatu keuntungan yang tidak sesuai dengan kewajiban resmi dan hak-hak dari para pihak lain.

Menurut M Cholil Nafis, dalam tindakan korupsi sedikitinya terdapat tiga kejahatan yaitu: Pertama, kejahatan yang berdampak pada hilangnya uang negara sehingga tindakan korupsi yang akut akan menyebabkan hiangnya hajat hidup orang banyak, memperlebar kesenjangan sosial-ekonomi, dan menghilangkan hak keadilan, Kedua korupsi dapat menghilangkan hak hidup warga negara dan regulasi keuangan negara.negara yang korup akan menyebabkan lahirnya kemiskinan dan kebodohan, Ketiga, kejahatan korupsi menggerogoti kehormatan dan keselamatan generasi penerus (Kasiyanto, 2018: 32).

Menurut pendapat beberapa ahli, ada beberapa penyebab kenapa tindakan korupsi itu terjadi, yaitu:

Menurut Prof. Dr.Andi Hamzah, menyebutkan bahwa ada 4 faktor yang menyebabkan sehingga orang melakukan korupsi, yaitu (Hamzah, 2012. 13-21):

1) Kurang gaji/pendapatan

2) Latar Belakang kebudayaan/Kultur

3) Manajemen yang kurang baik

4) Modernisasi.

Sedangkan menurut Prof. Dr. Baharuddin Lopa, terdapat penyebab terjadinya tindak pidana korupsi, yaitu (Lopa, 1997: 171-172):

1) Kerusakan moral

2) Kelemahan sistem

3) Kerawanan kondisi sosial ekonomi

4) Ketidaktegasan dalam penindakan hukum

5) Seringnya pejabat meminta sumbangan kepada pengusaha-pengusaha

6) Pungli

7) Kekurangan pengertian tentang tindak pidana korupsi 
8) Penyelenggaraan pemerintah dan pembangunan yang serba tertutup

9) Masih perlunya peningkatan mekanisme kontrol oleh DPR

10) Masih lemahnya perundang-undangan yang ada

11) Gabungan dari sejumlah faktor (penyebab)

Menurut Boni hargen, membagi penyebab terjadi korupsi menjadi 3 wilayah yaitu (Maharso \& Sujarwadi, 2018: 4):

1) Wilayah Individu, dikenal sebagai aspek manusia yang menyangkut moralitas personal serta kondisi situasional seperti peluang terjadinya korupsi termasuk didalamnya adalah faktor kemiskinan

2) Wilayah sistem, dikenal sebagai aspek institusi/administrasu korupsi dianggap sebagai konsekuensi dari kerja sistem yang tidak efektif. Mekanisme kontrol yang lemah dan kerapuhan sebuah sistem memberi peluang terjadinya korupsi

3) Wilayah Irisian antar individu dan Sistem, dikenal dengan aspek sosial budaya, yang meliputi hubungan antara politisi, unsur pemerintah dan organisasi non pemerintah. selai itu juga meliputi kultur masyarakat yang cenderung permisif dan kurang peduli dengan hal-hal yang tidak terpuji. Disamping itu terjadinya pergeseran nilai, logika, sosial dan ekonomi yang ada dalam masyarakat.

Jack Bologne yang dikenal dengan teori "Gone Theory mengemukakan bahwa faktor-faktor yang menyebabkan terjadinya korupsi meliputi Greeds (Keserakahan), Opportunities (kesempatan), Needs (Kebutuhan) dan Exposure (pengungkapan). Faktor internal penyebab korupsi adalah semua faktor atau variabel dalam individu, seperti sidat tamak/rakus, moral yang kurang kuat, cenderung mudah tergoda untuk korupsi, gaya hidup yang konsumptif tidak diimbangi dengan pendapatan.Faktor eksternal penyebab korupsi adalah sema faktor atau variabel diluar individu seperti norma sosial yang menjadi acuan perilaku kelompok masyarakat tertentu.Misalnya, masyarakat menghargai seseorang karena kekayaan yang dimilikinya, sedangkan dari aspek ekonomi karena pendapatan tidak mencukupi kebutuhan (Syahroni et al., 2018: 30).

Sedangkan menurut Yamamah (Siregar, 2017: 47) Ketika perilaku konsumtif dan materialistik masyarakat serta sistem politik yang masih "mendewakan" materi maka dapat "memaksa" terjadinya permainan uang dan korupsi. Susila (dalam Hamzah, 2004) menyebutkan tindakan korupsi juga mudah timbul karena ada kelemahan di dalam peraturan perundang-undangan, yang mencakup: (a) adanya peraturan perundang- undangan yang bermuatan kepentingan pihak-pihak tertentu (b) kualitas peraturan perundang-undangan kurang memadai, (c) peraturan kurang disosialisasikan, (d) sanksi yang terlalu ringan, (e) penerapan sanksi yang tidak konsisten dan pandang bulu, (f) lemahnya bidang evalusi dan revisi peraturan perundang-undangan. (Hamzah, 2004: 18) Indonesia Corruption Watch secara umum menjelaskan faktor penyebab korupsi dapat terjadi karena faktor politik, hukum dan ekonomi, dan birokrasi serta faktor transnasional (Indonesia Corruption Watch, 2000: 71). 
Berbeda dengan para ahli diatas, menurut penasihat Komisi Pemberantasan Korupsi (KPK) Abdullah Hehamahua dalam buku Ermansjah Djaja: "Tipologi Tindak Pidana Korupsi", menyatakan bahwa berdasarkan kajian dan pengalaman setidaknya ada deapan penyebab terjadinya tindak pidana korupsi di Indonesia, yaitu (Djaja, 2010: 49-51):

1) Sistem penyelenggaraan negara yang keliru

2) Kompensasi PNS yang rendah

3) Pejabat yang serakah

4) Law enforcement tidak berjalan

5) Hukuman yang ringan terhadap koruptor

6) Pengawasan yang tidak efektif

7) Tidak ada keteladanan pemimpin

8) Budaya masyarakat yang kondusif KKN (Korupsi, Kolusi dan Nepotisme).

Korupsi itu terjadi juga karena ketika kekuasaan dan kewenangan yang dimiliki pejabat publik tidak disertai kontrol atau mekanisme pertanggungjawaban terhadap publik yang memadai.Akibatnya, kekuasaan yang dimiliki itu dimonopoli sedemikian rupa dan hanya segelintir orang yang dekat kekuasaan saja yang ikut terlibat dalam proses penyusunan sebuah kebijakan. Mereka pula para pejabat dan para kroninya, yang mendapatkan keuntungan dari kebijakan itu, dalam situasi monopolistik seperti itu, pejabat berwenang memberikan kekuasaan atas implementasi kebijakan berupa pryek pembangunan kepada kroninya. Kurangnya kontrol publik disinilah yang menyebabkan proyek-proyek ini dikorupsi dalam berbagai bentuk (Hidayat, 2005: 2).

Kasus korupsi seperti yang dijelaskan diatas terus terjadi disebabkan juga karena masih banyak orang yang memanfaatkan dan menyalahgunakan jabatan dan akses yang dipunyai seorang pimpinan/Direksi BUMD untuk bisa mengatur dan mengelola keuangan yang dimiliki BUMD. Kasus yang menjadi fokus penelitian ini adalah kasus korupsi di banten dimana Direktur salah satu BUMD di Serang, Banten, tersangka TBS ditetapkan sebagai tersangka kasus korupsi yang merugikan Negara sampai Rp 1,8 Miliar. TBS ditetapkan sebagai tersangka terkait jabatannya di PT Lembaga Keuangan Mikro (LKM) Ciomas yang merupakan Badan Usaha Milik Daerah (BUMD) Kabupaten Serang. Selain TBS, kejaksaan juga menetapkan tersangka lainnya yaitu NA, menjelaskan kasus yang menjerat TBS, NA dan AT (yang sudah divonis 2 tahun penjara) diduga berawal dari korupsi anggaran BUMD pada 2016. Dari hasil audit, ditemukan ada kerugian negara Rp 1,8 miliar.

Tersangka TBS diduga mengeluarkan kas perusahaan sebesar Rp 900 juta untuk menanggulangi uang tabungan warga yang telah disalahgunakan oleh oknum di perusahaan.Selain itu, tersangka juga diduga melakukan pinjaman Rp 150 juta dan memerintahkan Kabag Kas AT untuk membayar angsuran menggunakan uang kas perusahaan Perusahan Daerah Perkrefditan Kecamaan (PD PK) Ciomas dengan total Rp 232 juta (Rifa'i, 2019).

Adanya kasus seperti dijelaskan atas menunjukkan jika manajemen BUMD belum dikelola dengan baik karena belum berjalannya fungsi perencanaan dan 
pengendalian dan masih belum dipahaminya prinsip transparansi dan akuntabilitas. BUMD merupakan badan usaha milik daerah yang tujuan pembentukannya salah satunya adalah melayani kepentingan masyarakat atau publik. Hal ini menandakan bahwa sudah seharusnya BUMD melaksanakan prinsip akuntabilitas, transparansi dan pertanggungjawaban dalam pengelolaan anggaran, adapun wujud dari ketiga prinsip tersebut adalah dibuatnya laporan pertanggungjawaban. Dalam pengelolaan anggaran harus akuntabilitas dan transparansi, mengingat salah 4 satu elemen penting dari perwujudan Good Coorporate Governance (GCG) adalah pengelolaan angggaran yang baik.Agar pengelolaan anggaran dapat berjalan dengan baik dan tepat sasaran maka dibutuhkan pengawasan dari atasan secara langsung dan badan legislatif serta lembaga pengawas yang khusus dibentuk untuk mengendalikan perencanaan dan pelaksanaan anggaran. Adanya pengawasan akan membuat perencanaan anggaran yang disusun dapat berjalan secara efisien, efektif dan ekonomis (Mardiasmo, 2002: 4-5).

Berdasarkan pada kasus yang sudh dijabarkan, dapat dianalisa bahwa didalam kasus ini terjadi tidak transparannya suatu pengelolaan dalam BUMD dimana pelaku didalam kasus ini melakukan tindakan penggunaan yang tidak sesuai dengan peruntukannya didalam pengelolaan keuangan BUMD nya. Dimana laporan keuangan yang dibuat oleh pelaku dibuat dengan tidak semestinya, dimana didalam laporan keuangan BUMD nya sudah dimasukkan data-data keuangan akan tetapi didalam penggunaannya dilapangan pelaku melakukan penggunaannya tidak sesuai dengan peruntukannya untuk penggunaan dananya. Sehingga penggunaan keuangannya tidak sesuai dengan laporan keuangan. Hal inilah yang menjadi temuan BPK pada saat auditor menemukan penggunaan transaksi BUMD pada laporan keuangan BUMD yang tidak dipergunakan dengan senyatanya .Dimana penggunaan anggaran dilapangan tidak sesuai dengan apa yang tercantum didalam laporan keuangan BUMD.

Berdasarkan pada analisis yang sudah dibuat diatas maka dapat diketahui bahwa Pelaku tertangkap melakukan tindakan penggunaan yang tidak sesuai dengan peruntukannya dengan alasan bahwa Laporan keuangan yang sudah dibuat untuk BUMD tersebut digunakan oleh pelaku dalam penggunaannya tidak sesuai dengan peruntukannya sehingga apa yang tercantum dalam laporan BUMD tidak sesuai lagi penggunaan anggaran yang sebenarnya.

Sebagai sebuah perbandingan, jika transparansi telah dilaksanakan dengan baik dalam pengelolaan BUMD, maka BUMD dapat bekerja dengan baik dan teratur. Sebagai contoh salah satu contoh BUMD yang juga berasal dari banten yang menggunakan prinsip transparansi didalam pengelolaan BUMD nya. Yaitu BANK BJB (Bank Pembangunan).

Dimana BANK BJB ini sudah melakukan beberapa macam cara sebagai bentuk transparansi dengan mencegah dan membasmi korupsi dan gratifikasi didalam BANK BJB, yaitu dengan cara:

1) Sistem Sumber Daya Manusia 
BANK BJB tengah melakukan transformasi total. Salah satu transformasi yang dilakukan adalah dengan melakukan pembenahan pada sistem sumber daya manusia. Akselerasi karir pegawai hanya dapat diraih berdasarkan prestasi kinerja yang dinilai secara objektif. Hal tersebut tentu menjawab pertanyaan miring tanpa dasar jika BUMN atau BUMD identik dengan tindakan nepotisme, termasuk tentang rekrutmen pegawai. Langkah tersebut direalisasikan melalui konsep blended learning solution. Pegawai BANK BJB dituntut terus belajar tanpa henti dan tidak menunggu untuk menjadi pintar. Terdapat tiga grand design dalam konsep bjb blended learning solution yakni learning by doing, learning by other dan learning by training.

2) Pembentukan Unit Pengendali Gratifikasi;

Gratifikasi merupakan cikal bakal dari tindakan koruptif. Menyadari hal tersebut, BANK BJB bekerjasama dengan KPK membentuk Unit Pengendali Gratifikasi (UPG) pada tahun 2011 lalu. UPG merupakan kepanjangan tangan dari KPK yang didirikan sebagai komitmen BANK BJB dalam mendukung program pemerintah terkait pemberantasan korupsi. Pasalnya, aktivitas gratifikasi di kehidupan bisnis kerap kali dipandang sebagai kebiasaan yang lumrah dan menjadi bentuk dari perilaku ramah tamah. Untuk itu praktiknya dianggap wajar dan mendarah daging. Sehingga penolakan gratifikasi dalam ranah bisnis akan berdampak pada hubungan dan kerjasama kedua pihak. UPG hadir sebagai jalan tengah karena pegawai dapat menerima bentuk gratifikasi untuk kemudian dilaporkan. Selanjutnya UPG akan mengelola dan melakukan penilaian yang komprehensif serta objektif mengenai bentuk gratifikasi.

3) Kegiatan Keagamaan

Pada tahun 2018, BANK BJB telah meresmikan Masjid Baitul Mughni yang berlokasi di kantor pusat di Kota Bandung. Pembangunan masjid tersebut merupakan representasi dari niat BANK BJB dalam meningkatkan ukhuwah islamiyah di lingkungan kerjanya.Aktivitas keagamaan dan siraman rohani rutin digelar oleh unit khusus yakni Badan Pembina Kerohanian Islam (Bapekis) BANK BJB. Diharapkan hal tersebut dapat menghindarkan insan BANK BJB dengan perbuatan tercela seperti korupsi dan lainnya.

Berkat kerja keras yang dilakukan BANK BJB didalam hal membuat transparansi dalam pengelolaannya yaitu dalam bentuk pencegahan dan pembasmian Korupsi dan gratifikasi BANK BJB sudah banyak mendapatkan penghargaan dari KPK sejak tahun 2012 sampai yang terbaru pada bulan desember tahun 2018 lalu dengan penghargaan "Lembaga dengan tingkat kepatuhan LHKPN terbaik". Penghargaan pengendalian Gratifikasi dan LKHPN (Laporan Harta Kekayaan Penyelenggara Negara) ini menunjukkan BANK BJB sebagai perbankan yang dapat memberikan nilai tambah bagi pemegang saham untuk menjaga kepercayaan yang telah diberikan oleh para pemangku kepentingan seperti nasabah, 
investor, pemegang saham, masyarakat umum serta insan BANK BJB (HaloNews, 2018).

Berdasakan kasus yang sudah dijabarkan diatas mengenai tidak transparansinya BUMD. Hal ini tentu sudah melanggar dan tidak mengikuti Pengelolaan BUMD yang sesuai dengan Peraturan Pemerintah Nomor 54 Tahun 2017 tentang Badan Usaha Milik Desa. Dimana didalam PP tersebut sudah sangat jelas dan mengatur tentang didalam proses pengelolaan dan tata kelola perusahaan yang baik salah satunya adalah tranparansi dimana hal itu juga bertujuan untuk mengoptimalkan nilai BUMD, mendorong pengelolaan BUMD agar professional, efisien dan efektif serta memberdayakan fungsi dan meningkatkan kemandirian organ BUMD, dan juga mendorong BUMD agar organ BUMD dalam membuat keputusan dan menjalankan tindakan dilandasi nilai moral yang tinggi dan kepatuhan terhadap peraturan perundang-undangan, serta kesadaran tanggung jawab sosial BUMD terhadap pemangku kepentingan maupun kelestarian lingkungan di sekitar BUMD.

Hal inilah yang masih sering menjadi masalah besar untuk BUMD di Indonesia, didalam hal menguatkan prinsip transparansi dalam pengelolaan BUMD maka sudah seharusnya bahwa Pemerintah harus membuat suatu peraturan yang lebih spesifik dalam hal penggunanaan prinsip transparansi didalam pelaporan keuangan yang dimana harus sesuai diantara Pengeluaran, pemasukan dan pengelolaan data didalam pelaporan keuangan, selain itu pemerintah harus melakukan evaluasi kembali mengenai peraturan dan pengawasan didalam pelaporan keuangan sebuah BUMD sehingga bisa diperketat dan juga dapat menghasilkan sebuah BUMD yang professional,efektif,efisien dan transparansi didalam pengelolaan dan pelaporan keuangannya, dan juga yang harus dilakukan oleh para direksi/pimpinan BUMD yaitu menekankan kepada para bawahannya didalam kepatuhan terhadap regulasi / peraturan yang mengatur tentang pengelolaan BUMD yang baik dan benar.

\section{Kesimpulan}

Berdasarkan yang sudah dijelaskan diatas maka dapat disimpulkan bahwa prinsip Transparansi didalam pengelolaan BUMD merupakan suatu unsur yang sangat penting didalam pengelolaan BUMD yang baik, dimana tanpa adanya prinsip transparansi maka akan banyak sekali kesempatan didalam pengelolaaan BUMD untuk bisa digunakan tidak sesuai dengan peruntukannya, yang bertujuan untuk mendapatkan keuntungan. Pentingnya prinsip transparansi juga merupakan suatu faktor penting yang menentukan pengelolaan BUMD yang professional, Efisien dan efektif. Prinsip Transparansi juga merupakan wujud dari peningkatan manajemen pengelolaan dan penyelenggaraan BUMD yang baik dan mengurangi kesempatankesempatan untuk terjadinya KKN (Korupsi, Kolusi dan Nepotisme) didalam BUMD itu sendiri, dan juga apabila didalam BUMD yang mempunyai cara pelaporan keuangan yang transparan maka bisa menimbulkan kontribusi yang baik kepada perekonomian daerah baik dari keuntungan secara profit tapi juga bisa meningkatkan usaha yang kondusif bagi perekonomian daerah dan dalam ruang 
lingkup yang lebih luar perekonomian nasional. Sehingga dapat memberikan pemasukan yang baik untuk daerahnya.

\section{Daftar Referensi}

Alwi, S. (2002). Paradigma Baru Peningkatan Kinerja Badan Usaha Milik Daerah (BUMD). Jurnal Siasat Bisnis, 1(7), 81-91.

Amdanata, D. D., Yusriadi, Mansor, N., \& Lestari, N. N. (2019). Implementasi Asas Transparansi Good Corporate Governance pada BUMD di Indonesia. Inovbiz: Jurnal Inovasi Bisnis, 7(2), 154-161.

Andrianto, N. (2007). Good E-Goverment : Tranparansi dan Akuntabilitas Publik melalui E-Goverment. Bayumedia Publishing.

Azre, I. A. (2017). Analisis Good Corporate Governance (GCG) Pada Badan Usaha Milik Daerah (BUMD) Provinsi Sumatera Barat (Studi Kasus PT Grafika Jaya Sumbar). Jurnal Administrasi Dan Kebijakan Publik, 2(3), 187-203. https:// doi.org/10.25077/jakp.2.3.187-203.2017

Bappenas, \& Depdagri. (2002). Buku Pedoman Penguatan Pengamanan Program Pembangunan Daerah. Bappenas dan Depdagri.

BKSI. (2001). Mencari Format Dan Konsep Transparansi Dalam Penyelenggaraan Pemerintahan Daerah. Menciptakan Transparansi Penyelenggaraan Pemerintahan Daerah : Memberdayakan Momentum Reformasi.

Black, H. C. (1990). Black Law Dictionary With Pronounciations. West Publishing Co.

Bushman, R. M., \& Smith, A. J. (2003). Transparency, Financial Accounting Information, and Corporate Governanc. Economic Policy Review, 9(1), 65-87.

Djaja, E. (2010). Tipologi Tindak Pidana Korupsi Di Indonesia. Mandar Maju.

HaloNews. (2018). Komitmen BJB pada Pengendalian Gratifikasi, Berbuah Penghargaan dari KPK. HaloNews. https:/ / halonewsbandung.wordpress.com/2018/12/06/komitmen-bjb-padapengendalian-gratifikasi-berbuah-penghargaan-dari-kpk/

Hamzah, A. (2004). Korupsi di Indonesia: Masalah dan Pemecahannya. Gramedia Pustaka Utama.

Hamzah, A. (2012). Hamzah Pemberantasan Korupsi Melalui Hukum Pidana Nasional Dan Internasional. Rajawali Pers.

Harefa, M. (2016). Pengelolaan Bumd/Perusahaan Daerah Diprovinsi Sumatera Barat, Nusa Tenggara Barat Dan Kalimantan Selatan. Kajian, 15(2), 199-226.

Hidayat, A. (2005). Panduan Pengawasan Keuangan Daerah: Wawasan dan Instrumen Monitoring Tata Kelola Keuangan Daerah. Masyarakat Transparansi Indonesia.

Indonesia Corruption Watch. (2000). Peran Parlemen dalam Membasmi Korupsi. Indonesia Corruption Watch. 
Kamaluddin, R. (2011). Peran dan Pemberdayaan BUMD Dalam Rangka Peningkatan Perekonomian Daerah. Visi Media.

Kasiyanto, H. A. (2018). Teori dan Praktik Sistem Peradilan Tipikor Terpadu di Indonesia. Kencana Prenada Media Group.

Lopa, B. (1997). Masalah Korupsi dan Pemecahannya. Kipas Putih Aksara.

Maharso, \& Sujarwadi, T. (2018). Fenomena Korupsi Dari Sudut Pandang Epidemiologi. Deepublish.

Mardiasmo. (2002). Akuntansi Sektor Publik. Andi Offset.

Mardiasmo. (2004). Otonomi \& Manajemen Keuangan Daerah. Andi Offset.

P, L. L. K. (2003). Indikator E Alat Ukur Prinsip Akuntabilitas, Transparansi E Partisipasi. Sekertariat Good Public Governance Badan Perencanaan Pembangunan Nasional.

Pusat Bahasa Departemen Pendidikan Nasional. (2008). Kamus Besar Bahasa Indonesia. Balai Pustaka.

Rahman, M. G. (2000). Good Governance, Prinsip, Komponen, dan Penerapanya dalam Hak Asasi Manusia (Penyelenggaraan Negara Yang Baik). Komnas HAM.

Rifa'i, B. (2019). Kejaksaan Tetapkan Direktur BUMD di Banten Jadi Tersangka Korupsi. DetikNews. https://news.detik.com/berita/d-4788439/kejaksaan-tetapkandirektur-bumd-di-banten-jadi-tersangka-korupsi

Sarana, J. (2010). Revitalisasi Peran BUMD dalam Perekonomian Daerah: Studi Kasus BUMD Sektor Pariwisata di DKI Jakarta. LIPPI Press.

Siregar, S. L. (2017). Literature Review : Perilaku Korupsi dan Penyebabnya. Fundamental Management Journal, 2(1), 47-56.

Syahroni, Maharso, \& Sujarwadi, T. (2018). Korupsi, Bukan Budaya Tapi Penyakit. Deepublish. 